\title{
Mitigation Effect of K-Humate on $N, P$ and $K$ Phytoavailability in Three Different Egyptian Soils under Salinity Stress
}

Fatma K. Sherif and R. M. R. Hedia

Soil and Water Science Department, Faculty of Agriculture, University of Alexandria, Alexandria, Egypt.

\begin{abstract}
SOIL salinity has several adverse effects on phytoavailability of $\checkmark$ nutrients and plant growth in arid and semi-arid regions. This study investigated the mitigation effect of K-Humate application on the phytoavailability of $\mathrm{N}, \mathrm{P}$ and $\mathrm{K}$ nutrients in three different Egyptian soils; from Kafr El-Sheikh, West Nubaria and South AlTahrir under salinity stress condition using Amberlite IRN-150 resin capsules. Representative surface soil samples $(0-15 \mathrm{~cm})$ were artificially salinized through equilibrium with four electrolytic solutions having four salinity levels $(0,5,20$ and 40 me/l, SAR=7) prepared using mixtures of $\mathrm{Na}_{2} \mathrm{SO}_{4}$ and $\mathrm{CaCl}_{2}$ salts $(\mathrm{S} 1, \mathrm{~S} 2, \mathrm{~S} 3$ and $\mathrm{S} 4$, respectively). Soils were then treated with $0,1,2$ and $3 \mathrm{~g} \mathrm{~K}$ Humate/kg soil under each salinity level. Pots were subjected to drying/rewetting cycles for a period of 60 days then resin capsules were inserted into the soil, incubated for 14 days at soil water FC and phytoavailability of $\mathrm{N}, \mathrm{P}$ and $\mathrm{K}$ were measured (RAQ, g/ $\mathrm{cm}^{2}$ ). Results showed that increasing soil salinity had significantly adverse effects on N-RAQs and P-RAQs. Application of K-Humate significantly increased N-RAQs and P-RAQs up to the rate of $2 \mathrm{~g} \mathrm{~K}$-Humate $/ \mathrm{kg}$ soil under each salinity level in the three tested soils. The highest percent increase in N-RAQs and P-AQs were found to be at the highest salinity level S4. While K-RAQs was not significantly affected by increasing soil salinity, it was significantly increased by increasing K-Humate application rate. Further field research is required in diverse plant environments to assess economical feasibility of K-Humate and comparison with other manures and organic fertilizers.
\end{abstract}

Keywords: N/P/K phytoavailability, K-Humate, Soil salinity, Resin capsules, Egyptian soils.

Salinity is a major abiotic stress, reducing the yield of wide variety of crops all over the world (Tester \& Davenport, 2003 and Ashraf \& Foolad, 2007). Plants growing in saline media come across generally with major drawbacks. The first is the increase in the osmotic stress due to high salt concentration of soil solution that decreases water potential of soil. The second is the increase in concentration of sodium $\left(\mathrm{Na}^{+}\right)$and chloride $\left(\mathrm{Cl}^{-}\right)$ions, exhibiting tissue accumulation of these ions and inhibition of mineral nutrients uptake (Marschner, 1995 and Aşik et al., 2009). For overcoming the negative effect of salinity, the addition of 
supplemental organic matter (Walker and Bernal, 2008) to growth media as an ameliorative agent could be necessary.

Humic acid (HA) is a commercial product which is proposed to improve soil fertility and increase the availability of nutrient elements. It consequently affects plant growth and yield and ameliorates the deleterious effects of salt stress. Kulikova et al. (2005) indicated that humic substances might show anti-stress effects under abiotic stress conditions such as unfavorable temperature, salinity, $\mathrm{pH}$, etc. Humic substances are well known as stimulators of plant germination and growth (Dell'Amico et al., 1994 and Masciandaro et al., 2002). HA appeared to be highly effective as a soil conditioner in vegetable growth, to improve crop tolerance and plant uptake of nutrients under saline conditions (Aydil et al., 2012 and Daur \& Bakhashwain, 2013). Although the effect of interaction between salts and soil humus application was found statistically significant, the interaction effect between salt and HA foliar treatment was not found significant. Mesut Çimrin et al. (2010) concluded that HA application significantly increased N, P, $\mathrm{K}, \mathrm{Ca}, \mathrm{Mg}, \mathrm{S}, \mathrm{Mn}$ and $\mathrm{Cu}$ contents of shoot of pepper seedling. Also, N, P, K, $\mathrm{Ca}, \mathrm{S}, \mathrm{Fe}, \mathrm{Mn}, \mathrm{Zn}$ and $\mathrm{Cu}$ contents of root were increased with HA application. $\mathrm{Na}$ contents of both shoot and root of pepper decreased with increased HA doses. HA may also affect the rate and form in which $\mathrm{P}$ precipitates in calcareous soils. HA was found to inhibit the precipitation of hydroxyapatite (HAP) (Inskeep and Silverthooth, 1988) and to favor the formation of dicalcium phosphate dihydrate (DCPD) over other, more thermodynamically stable and less soluble phosphates and hence increases the efficiency of applied P fertilizer (Havlin \& Westfall, 1984; Grossl \& Inskeep, 1991 and Delgado et al., 2002).

Use of a resin sink to simulate nutrient movement to plant roots is a more realistic and sensitive test of nutrient availability than chemical-extraction procedures. Resin-accumulated nutrients were also significantly correlated with plant nutrient uptake under a variety of conditions (Sherif, 1996; Carlyle \& Malcolm, 1986 and van Raij et al., 1986). Furthermore, the use of a mixed- bed ion exchange resin sink allows adsorption of all ionic forms of nutrients that would be present at the root surface. In both living root systems and resinadsorption systems, nutrient ions continuously diffuse to the sink in response to gradients established by dynamic equilibrium. The mechanism is similar to the soil-root system, in which roots absorb nutrients from soil solution by releasing counter ions such as $\mathrm{H}^{+}$, $\mathrm{OH}^{-}$and $\mathrm{HCO}_{3}{ }^{-}$. Mixed-bed ion-exchange resin capsules (Yang et al., 1991) can be inserted into disturbed and undisturbed soil samples or directly installed under field conditions to obtain resin adsorption quantities per unit surface area, (RAQ, $\mathrm{g} / \mathrm{cm}^{2}$ or $\mu \mathrm{mol} / \mathrm{cm}^{2}$ ). Examples of their use include studies of $\mathrm{N}$ and $\mathrm{P}$ availability under field conditions, monitoring of nitrate dynamics (Wander et al., 1995), monitoring the availability and movement of nutrients in Egyptians soils (Sherif and Hedia, 2001), assessment of labile soil P using resin membrane (Cooperland and Logan, 1994), characterization of $\mathrm{K}$ release kinetics from soils and minerals (Wimaladasa \& Sinclair, 1988), monitoring the movements of elements in a forest soil (Haibara et al., 1990). Indeed, the results obtained by Hedia and Sherif (2004) provide strong evidence

Egypt. J. Soil Sci. 55, No.3 (2015) 
that the resin capsule is sensitive to salinity known to influence nutrient availability in soils.

The objective of this study was to investigate the mitigation effect of KHumate application on the phytoavailability of N, P and K nutrients in three different Egyptian soils under salinity stress condition using resin capsules.

\section{Material and Methods}

Soils

Three different soil samples were collected from Kafr El-Sheikh (Motobas), West Nubaria and South Al-Tahrir representing alluvial, calcareous and sandy soils, respectively. Three simple surface soil samples $(0-15 \mathrm{~cm})$ were randomly collected from each location and mixed together to form a composite representative sample. Soil samples were air dried, sieved at $2 \mathrm{~mm}$ and analyzed for their main characteristics according to the procedures outlined by Page et al. (1982) as shown in Table 1.

TABLE 1. Main characteristics of the studied soils.

\begin{tabular}{|c|c|c|c|}
\hline Criteria & $\begin{array}{c}\text { Kafr } \\
\text { El-Sheikh }\end{array}$ & $\begin{array}{c}\text { Soils } \\
\text { West Nubaria }\end{array}$ & $\begin{array}{c}\text { South } \\
\text { Al-Tahrir }\end{array}$ \\
\hline Bulk Density, $\mathrm{kg} / \mathrm{m}^{3}$ & 1.28 & 1.46 & 1.69 \\
\hline \multicolumn{4}{|l|}{ Particle Size Distrib. \% } \\
\hline Sand & 69.3 & 71.3 & 92.3 \\
\hline Silt & 17.2 & 23.4 & 6.3 \\
\hline Clay & 13.5 & 5.3 & 1.4 \\
\hline Texture Class & $\mathrm{CL}$ & SCL & S \\
\hline $\mathrm{EC}, \mathrm{dS} / \mathrm{m}$ & 1.18 & 1.89 & 2.11 \\
\hline $\mathrm{pH}$ & 8.12 & 8.32 & 7.82 \\
\hline SAR & 8.97 & 9.41 & 9.98 \\
\hline Total $\mathrm{CaCO}_{3}, \%$ & 7.12 & 35.67 & 6.13 \\
\hline Organic Matter, \% & 2.43 & 1.49 & 0.57 \\
\hline $\mathrm{CEC}, \mathrm{cmol}_{\mathrm{C}} / \mathrm{kg}$ & 19.64 & 11.61 & 5.47 \\
\hline \multicolumn{4}{|l|}{ Availability, mg/kg } \\
\hline $\mathrm{N}$ & 42.2 & 34.6 & 14.7 \\
\hline $\mathrm{P}$ & 21.3 & 12.3 & 10.4 \\
\hline $\mathrm{K}$ & 54.1 & 19.1 & 6.4 \\
\hline
\end{tabular}

\section{Humic substances}

A commercial K-Humate powder from Germany was used in treating the studied soils. The main characteristics of the product were determined according to Page et al. (1982). It was found that this product contains $58.12 \%$ OC, $0.41 \%$ $\mathrm{N}, 0.09 \% \mathrm{P}$ and $1.45 \% \mathrm{~K}$ with a CEC of $214.11 \mathrm{cmol}_{\mathrm{c}} / \mathrm{kg}$. 


\section{Treatments}

Four electrolytic solutions were prepared with different salinity levels of 0,5 , 20 and $40 \mathrm{meq} / \mathrm{L}$ (S1, S2, S3 and S4, respectively) using a mixture of $\mathrm{Na}_{2} \mathrm{SO}_{4}$ and $\mathrm{CaCl}_{2}$ salts. The SAR of all solutions was kept at 7 to avoid sodicity interferences. Four portions of $3.5 \mathrm{~kg}$ of each soil were packed in suitable plastic pots and continuously leached with these electrolytes until the EC of the leachates were equilibrated. Treated soils were then air-dried, crushed and sieved at $2 \mathrm{~mm}$. The four portions of each soil were fertilized with ammonium sulfate and triple superphosphate at rates of $150 \mathrm{~kg} \mathrm{~N} / \mathrm{fed}$. and $100 \mathrm{~kg} \mathrm{P} / \mathrm{fed}$, respectively. Potassium fertilizer was not applied based on K- Humate used as a source for humate and K. Each portion for each soil was then divided into four sub-portions which were treated with $0,1.0,2.0$ and $3.0 \mathrm{~g} \mathrm{~K}-\mathrm{Humate} / \mathrm{kg}$ soil (H1, $\mathrm{H} 2, \mathrm{H} 3$ and $\mathrm{H} 4$, respectively). The treated soils were then packed in $330 \mathrm{ml}$ plastic pots. The pots were brought to their water holding capacity using distilled water. Pots were subjected to drying and rewetting cycles with distilled water at room temperature along a period of 60 days.

\section{Resin capsules}

The Amberlite IRN-150 resin capsules were used for measuring the phytoavailability soil test (PST) of N, P and $\mathrm{K}$ in the treated soils according to Skogley (1992) and Sherif \& Hedia (2001). These capsules provide a system that simulates ion movement to plant roots, where ions of all types are accumulated simultaneously and independently (Skogley, 1992 and 1994). They have a constant, uniform surface area, a feature that is critical to precision and comparison of values among and between samples. When placed in soil, water, or other media, cations and anions will be accumulated simultaneously creating universal system.

At the end of wetting and drying cycles, the soils were brought to their field capacity and one Amberlite resin capsule was inserted in each treated soil pot. The pots were sealed with plastic covers to prevent water evaporation. After incubation for 14 days at room temperature (Skogley, 1994), resin capsules were taken out of the soil and rinsed with distilled water and then leached with $50 \mathrm{ml}$ of $2.0 \mathrm{M} \mathrm{HCl}$ and the leachate was received in a $50-\mathrm{ml}$ measuring flask. The amount of attained nutrients is quantitatively measured in terms of resin absorption quantity (RAQ, $\mu \mathrm{g} / \mathrm{cm}^{2}$ ).

\section{Measurements}

The quantities of $\mathrm{N}, \mathrm{P}$ and $\mathrm{K}$ were determined in the leachates of the resin capsules which represent the resin adsorption quantities (N, P and K-RAQ, $\mu \mathrm{g} / \mathrm{cm}^{2}$, respectively) of these nutrients. Nitrogen was measured using Buchi distillation unit (Model K-350) according to the Kjeldahl method (Keeney and Nelson, 1982). Phosphorus was determined colorimetrically according to Page et al. (1982) using Shimadzu spectrophotometer (Model UV 1208). Potassium was determined using the Corning flame photometer (Model 400). All measurements were done in duplicates.

Egypt. J. Soil Sci. 55, No.3 (2015) 


\section{Statistical analysis}

The data collected were analyzed statistically according to the procedures given by Steel and Torrie (1980) to test the significance of the differences between means of the applied treatments using the CoStat software package (Costat, 2004). All measurements were in triplicates. The percent change in measured N-RAQs, P-RAQs and K-RAQs relative to the control (\%RAQ $\left.Q_{\text {change }}\right)$ due to the applied K-Humate and salinity treatments was also calculated as follows:

$$
\% R A Q_{\text {change }}=\frac{\left(R A Q_{T}-R A Q_{c}\right)}{R A Q_{c}} \times 100
$$

where $R A Q_{T}$ and $R A Q_{C}$ are the measured RAQ values under any treatment and the control, respectively.

\section{Results and Discussion}

Results of the effect of K-Humate application on mineral N-RAQ values (Fig. 1) showed that Kafr El-Sheikh soil had generally higher N-RAQs $\left(63.95 \mu \mathrm{g} / \mathrm{cm}^{2}\right)$ compared to West Nubaria $\left(52.01 \mu \mathrm{g} / \mathrm{cm}^{2}\right)$ and South Al-Tahrir $\left(55.36 \mu \mathrm{g} / \mathrm{cm}^{2}\right)$ soils. This may be due to the higher initial available mineral nitrogen and soil organic matter content of Kafr El-Seikh soil (Table 1). N-RAQs generally increased with increasing the K-Humate application rate (1,2 and $3 \mathrm{~g} / \mathrm{kg}$ soil) in the three tested soils under each salinity level. However, increasing the salinity level in the three soils from S1 through S4 had an adverse effect on the N-RAQs under each K-Humate application rate. The lowest N-RAQs were obtained at the highest salinity level (S4) in the three soils. Statistical analysis of the obtained results (Tables 2 and 3) revealed that application of K-Humate at 1 and $2 \mathrm{~g} / \mathrm{kg}$ had significant positive effects on N-RAQs under the three salinity levels in the three soils (Table 2). However, increasing the K-Humate application rate of KHumate to $3 \mathrm{~g} / \mathrm{kg}$ did not significantly increase N-RAQs in the three soils. The mitigation effect of K-Humate on mineral soil nitrogen availability is probably due to the modification of the soil conditions that favors nitrogen mineralization (Khaled \& Fawy, 2011 and Mesut Çimrin et al., 2010). The calculated percent increases in N-RAQs at $2 \mathrm{~g} / \mathrm{kg}$ of K-Humate, relative to the control, under different salinity levels in Kafr El-Sheikh soil were 62.11, 54.70, 45.47 and 10.59 $\%$, in West Nubaria soil were 33.94, 30.54, 20.38 and 103.39 \% and in South AlTahrir were $23.57,21.30,61.54$ and $122.42 \%$ at S1, S2, S3 and S4, respectively (Table 4). Increasing salinity level from S1 to S2 did not have significant effect on N-RAQs in the three soils (Table 3). However, increasing salinity to S3 and S4 had significantly negative effects on the measured N-RAQs in the three soils at each K-Humate application rate. This negative effect may be due to the unfavorable effect of increasing soil salinity on nitrogen mineralization process (Keeney and Nelson, 1982). 

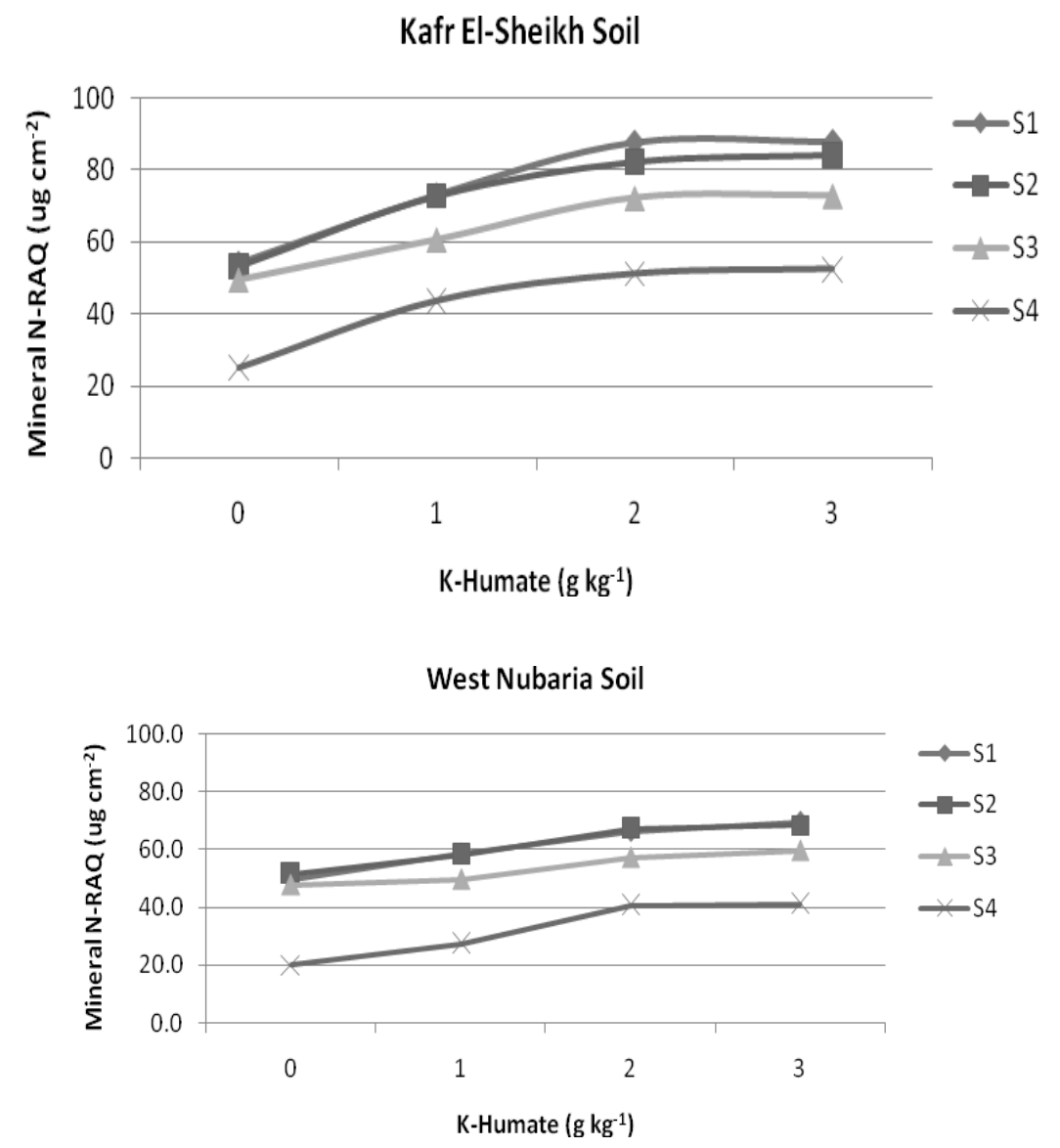

South Al-Tahrir Soil

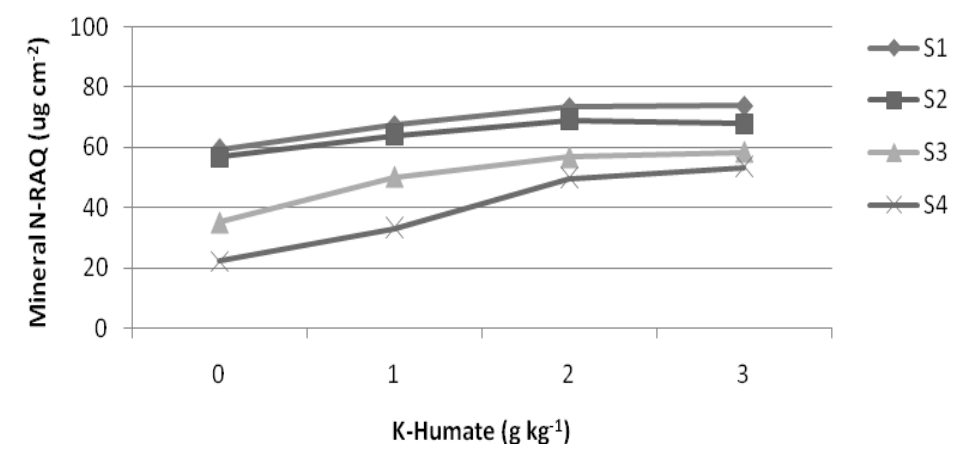

Fig. 1. Mineral N-RAQ values as affected by K-Humate application at different salinity levels in the three tested soils.

Egypt. J. Soil Sci. 55, No.3 (2015) 
TABLE 2. Means of RAQ values $\left(\mu \mathrm{g} / \mathrm{cm}^{2}\right)$ for $\mathrm{K}-\mathrm{Humate}$ treatments and their significance at $\mathrm{LSD}_{0.05}$ values.

\begin{tabular}{|c|c|c|c|c|c|}
\hline \multirow{2}{*}{ Soils } & \multirow{2}{*}{$\operatorname{LSD}_{.05}{ }^{*}$} & \multicolumn{4}{|c|}{ K-Humate Treatments $\left(\mathrm{g} \mathrm{kg}^{-1}\right)$} \\
\hline & & $\mathbf{0}$ & 1 & 2 & 3 \\
\hline \multirow[b]{2}{*}{ Kafr El-Sheikh } & \multicolumn{5}{|c|}{ Mineral N-RAQ } \\
\hline & 3.62 & $45.53 \mathrm{a}$ & $62.58 \mathrm{~b}$ & $73.35 c$ & $74.35 c$ \\
\hline West Nubaria & 4.87 & $42.11 \mathrm{a}$ & $48.43 b$ & $57.83 \mathrm{c}$ & $59.62 \mathrm{c}$ \\
\hline \multirow[t]{2}{*}{ South Al-Tahrir } & 6.76 & $43.40 \mathrm{a}$ & $53.65 \mathrm{~b}$ & $62.15 \mathrm{c}$ & $63.38 \mathrm{c}$ \\
\hline & \multicolumn{5}{|c|}{ P-RAQ values } \\
\hline Kafr El-Sheikh & 4.05 & $30.10 \mathrm{a}$ & $34.08 \mathrm{a}$ & $38.18 b$ & $40.18 b$ \\
\hline West Nubaria & 3.19 & $22.46 \mathrm{a}$ & $25.19 \mathrm{a}$ & $27.86 \mathrm{a}$ & $31.16 \mathrm{~b}$ \\
\hline \multirow[t]{2}{*}{ South Al-Tahrir } & 3.39 & $25.45 \mathrm{a}$ & $28.81 \mathrm{a}$ & $32.28 \mathrm{~b}$ & $33.70 \mathrm{~b}$ \\
\hline & \multicolumn{5}{|c|}{ K-RAQ values } \\
\hline Kafr El-Sheikh & 3.15 & $115.10 \mathrm{a}$ & $120.25 b$ & $129.43 c$ & $133.35 \mathrm{~d}$ \\
\hline West Nubaria & 2.71 & $98.33 \mathrm{a}$ & $105.65 b$ & $111.81 \mathrm{c}$ & $115.00 \mathrm{~d}$ \\
\hline South Al-Tahrir & 2.65 & $84.50 \mathrm{a}$ & $87.75 b$ & $92.03 \mathrm{c}$ & $92.68 \mathrm{c}$ \\
\hline
\end{tabular}

$*$ For $\mathrm{n}=12$, values followed by the same letter are not significantly different.

TABLE 3. Means of RAQ values $\left(\mu \mathrm{g} / \mathrm{cm}^{2}\right)$ for salinity treatments and their significance at $\mathrm{LSD}_{.05}$ values.

\begin{tabular}{|c|c|c|c|c|c|}
\hline \multirow{2}{*}{ Soils } & \multirow{2}{*}{ LSD $_{.05}{ }^{*}$} & \multicolumn{4}{|c|}{ Salinity Treatments $\left(\mathrm{g} \mathrm{kg}^{-1}\right)$} \\
\hline & & S1 & S2 & S3 & $\mathbf{S 4}$ \\
\hline \multirow[b]{2}{*}{ Kafr El-Sheikh } & & & \multicolumn{2}{|c|}{ Mineral N-RAQ } & \\
\hline & 3.11 & $75.70 \mathrm{a}$ & $73.13 \mathrm{a}$ & $63.93 b$ & $43.05 \mathrm{c}$ \\
\hline West Nubaria & 2.67 & $61.00 \mathrm{a}$ & $61.23 \mathrm{a}$ & $53.50 \mathrm{~b}$ & $32.27 \mathrm{c}$ \\
\hline \multirow[t]{2}{*}{ South Al-Tahrir } & 4.25 & $68.53 \mathrm{a}$ & $64.38 \mathrm{a}$ & $50.08 \mathrm{~b}$ & $39.60 \mathrm{c}$ \\
\hline & \multicolumn{5}{|c|}{ P-RAQ values } \\
\hline Kafr El-Sheikh & 2.98 & $41.95 \mathrm{a}$ & $39.78 \mathrm{a}$ & $36.45 b$ & $24.35 \mathrm{c}$ \\
\hline West Nubaria & 2.14 & $31.45 \mathrm{a}$ & $30.17 \mathrm{a}$ & $25.18 \mathrm{~b}$ & $18.36 \mathrm{c}$ \\
\hline \multirow[t]{2}{*}{ South Al-Tahrir } & 2.35 & $35.03 \mathrm{a}$ & $33.85 \mathrm{a}$ & $31.35 \mathrm{~b}$ & $20.01 \mathrm{c}$ \\
\hline & \multicolumn{5}{|c|}{ K-RAQ values } \\
\hline Kafr El-Sheikh & 2.79 & $124.03 \mathrm{a}$ & $123.43 \mathrm{a}$ & $124.28 \mathrm{a}$ & $126.40 \mathrm{a}$ \\
\hline West Nubaria & 3.14 & $109.00 \mathrm{a}$ & $106.96 \mathrm{a}$ & $107.65 \mathrm{a}$ & $107.18 \mathrm{a}$ \\
\hline South Al-Tahrir & 2.87 & $89.15 \mathrm{a}$ & $89.33 \mathrm{a}$ & $89.08 \mathrm{a}$ & $88.40 \mathrm{a}$ \\
\hline
\end{tabular}

$*$ For $n=12$, values followed by the same letter are not significantly different. 
TABLE 4. Increase percent in mineral N-RAQ values relative to the control.

\begin{tabular}{|c|c|c|c|c|}
\hline \multirow{2}{*}{ Soils } & \multirow{2}{*}{$\begin{array}{c}\text { Salinity } \\
\text { Treatments }\end{array}$} & \multicolumn{3}{|c|}{ K-Humate Treatments $\left(\mathrm{g} \mathrm{kg}^{-1}\right)$} \\
\hline & & 1 & 2 & 3 \\
\hline \multirow{4}{*}{ Kafr El-Sheikh } & $\mathrm{S} 1$ & 35.12 & 62.11 & 62.48 \\
\hline & S2 & 36.84 & 54.70 & 58.27 \\
\hline & S3 & 22.33 & 45.47 & 46.68 \\
\hline & S4 & 73.71 & 103.59 & 108.76 \\
\hline \multirow[t]{4}{*}{ West Nubaria } & S1 & 18.38 & 33.94 & 40.61 \\
\hline & S2 & 13.04 & 30.54 & 32.88 \\
\hline & S3 & 4.23 & 20.38 & 24.97 \\
\hline & S4 & 37.31 & 103.69 & 105.97 \\
\hline \multirow[t]{4}{*}{ South Al-Tahrir } & S1 & 12.27 & 21.21 & 21.82 \\
\hline & S2 & 11.25 & 19.17 & 17.59 \\
\hline & S3 & 38.46 & 55.38 & 59.74 \\
\hline & S4 & 43.59 & 110.18 & 125.52 \\
\hline
\end{tabular}

Measured P-RAQ values (Fig. 2) showed that Kafr El-Sheikh soil had generally the highest P-RAQs $\left(35.63 \mu \mathrm{g} / \mathrm{cm}^{2}\right)$ and West Nubaria soil had the lowest values $\left(26.29 \mu \mathrm{g} / \mathrm{cm}^{2}\right)$. The higher $\mathrm{CaCO}_{3}$ content of West Nubaria soil may be a limiting factor for the lowest $\mathrm{P}$ solubility compared to the other two soils (Table 1). P-RAQs generally increased with increasing the K-Humate application rate in the three soils under each salinity level. However, increasing the salinity level in the three soils also had an adverse effect on the P-RAQs where the lowest P-RAQs were obtained at the highest salinity level (S4). Statistically, the application of $1 \mathrm{~g} / \mathrm{kg} \mathrm{K}$-Humate had no significant effect on PRAQs in the three soils (Table 2). However, increasing the K-Humate application rate to $2 \mathrm{~g} / \mathrm{kg}$ of K-Humate significantly increased P-RAQs in Kafer El-Sheikh and South Al-Tahrir soils only. Increasing the application rate of K-Humate to 3 $\mathrm{g} / \mathrm{kg}$ significantly increased P-RAQs in West Nubaria soil only.

The increase percent in P-RAQs at $2 \mathrm{~g} / \mathrm{kg}$ of K-Humate under different salinity levels in Kafr El-Sheikh soil were 28.09, 28.91, 21.73 and $29.08 \%$ and in South Al-Tahrir were 25.28, 26.02, 19.55 and $26.17 \%$ and at $3 \mathrm{~g} / \mathrm{kg}$ of KHumate in West Nubaria soil 26.31, 29.89, 29.41 and 50.08\% at S1, S2, S3 and S4, respectively (Table 5). The mitigation of phosphorus availability in soils amended with humic substances is attributed to the formation of organophosphorus soluble complexes between humate and phosphorus ions in the soil solution (Grossl \& Inskeep, 1991; Delgado et al., 2002 and Andrews et al., 2004). Similar to the response of N-RAQs to salinity levels, increasing salinity level in the soil from S1 to S2 did not have significant effect on P-RAQs in the three soils (Table 3). However, the increase of salinity to S3 and S4 had significantly negative effect on P-RAQs in the three soils at each K-Humate application rate. It was reported that increasing soil salinity led to the increase of Egypt. J. Soil Sci. 55, No.3 (2015) 
soluble $\mathrm{Ca}^{2+}$ concentration which precipitates soluble phosphorus from soil solution in the form of calcium phosphate (Andrews et al., 2004).
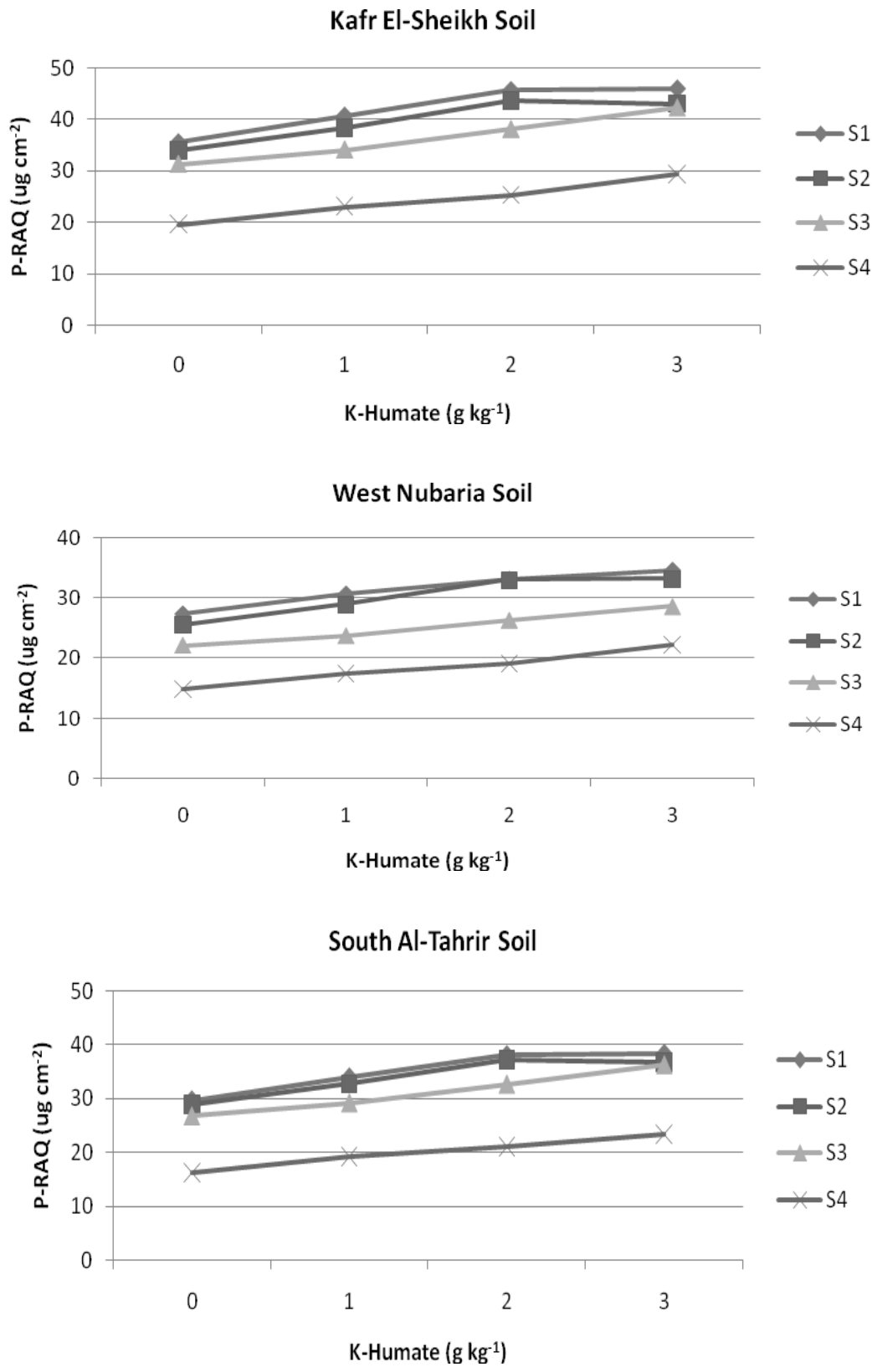

Fig. 2. P-RAQ values as affected by K-Humate application at different salinity levels in the three tested soils.

Egypt. J. Soil Sci. 55, No. 3 (2015) 
TABLE 5. Percent increase in P-RAQ values relative to the control.

\begin{tabular}{|c|c|c|c|c|}
\hline \multirow{2}{*}{ Soils } & \multirow{2}{*}{$\begin{array}{c}\text { Salinity } \\
\text { Treatments }\end{array}$} & \multicolumn{3}{|c|}{ K-Humate Treatments $\left(\mathrm{g} \mathrm{kg}^{-1}\right)$} \\
\hline & & 1 & 2 & 3 \\
\hline \multirow[t]{4}{*}{ Kafr El-Sheikh } & $\mathrm{S} 1$ & 14.33 & 28.09 & 28.93 \\
\hline & S2 & 13.27 & 28.91 & 27.14 \\
\hline & S3 & 8.95 & 21.73 & 35.14 \\
\hline & S4 & 17.86 & 29.08 & 50.00 \\
\hline \multirow[t]{4}{*}{ West Nubaria } & $\mathrm{S} 1$ & 12.00 & 20.80 & 26.31 \\
\hline & $\mathrm{S} 2$ & 13.27 & 28.91 & 29.89 \\
\hline & S3 & 7.24 & 19.00 & 29.41 \\
\hline & S4 & 17.36 & 29.18 & 50.08 \\
\hline \multirow[t]{4}{*}{ South Al-Tahrir } & $\mathrm{S} 1$ & 12.89 & 25.28 & 26.04 \\
\hline & $\mathrm{S} 2$ & 11.95 & 26.02 & 24.42 \\
\hline & $\mathrm{S} 3$ & 8.05 & 19.55 & 31.63 \\
\hline & S4 & 16.07 & 26.17 & 38.99 \\
\hline
\end{tabular}

Average K-RAQ values measured in the three soils (Fig. 3) showed the order: Kafr El-Sheikh> West Nubaria> South Al-Tahrir (124.53, 107.50 and 89.24 $\mu \mathrm{g} / \mathrm{cm}^{2}$, respectively). This trend may correspond to the differences in the CEC and initial available $\mathrm{K}$ of these soils (Table 1). K-RAQs generally increased with increasing the K-Humate application rate in the three soils under each salinity level. This may be due to the release of $\mathrm{K}$ from the applied potassium humate material. Increasing the salinity level in the three soils did not affect K-RAQs under each K-Humate application rate. Increasing the application rate of KHumate from 1 to $3 \mathrm{~g} / \mathrm{kg}$ had significant effect on K-RAQs except in South AlTahrir soil (Table 2). The increases percent in K-RAQs at $3 \mathrm{~g} / \mathrm{kg}$ of K-Humate under different salinity levels in Kafr El-Sheikh soil were 15.87, 15.36, 16.13 and $16.05 \%$ and in West Nubaria were 19.26, 16.43, 13.10 and $19.12 \%$ and at 2 $\mathrm{g} / \mathrm{kg}$ of K-Humate in South Al-Tahrir soil were 7.99, 9.25, 8.38 and $10.01 \%$ at S1, S2, S3 and S4, respectively (Table 6). On contrast with N-RAQs and PRAQs, increasing salinity level from $\mathrm{S} 1$ through $\mathrm{S} 4$ did not have any significant effects on K-RAQs at each K-Humate application rate in the three soils (Table 3). Since ions of all types in from the soil solution are accumulated simultaneously and independently on the exchange sites of resin capsules (Skogley, 1992, 1994), increasing salinity did not affect K-RAQs in the three soils.

It is also noticeable that the mitigation effect of K-Humate was pronounced mostly at the highest salinity level in the three soils. This was evidenced by the highest percent increases in calculated N-RAQs, P-RAQs and K-RAQs values (Tables 4 - 6).

Egypt. J. Soil Sci. 55, No.3 (2015) 

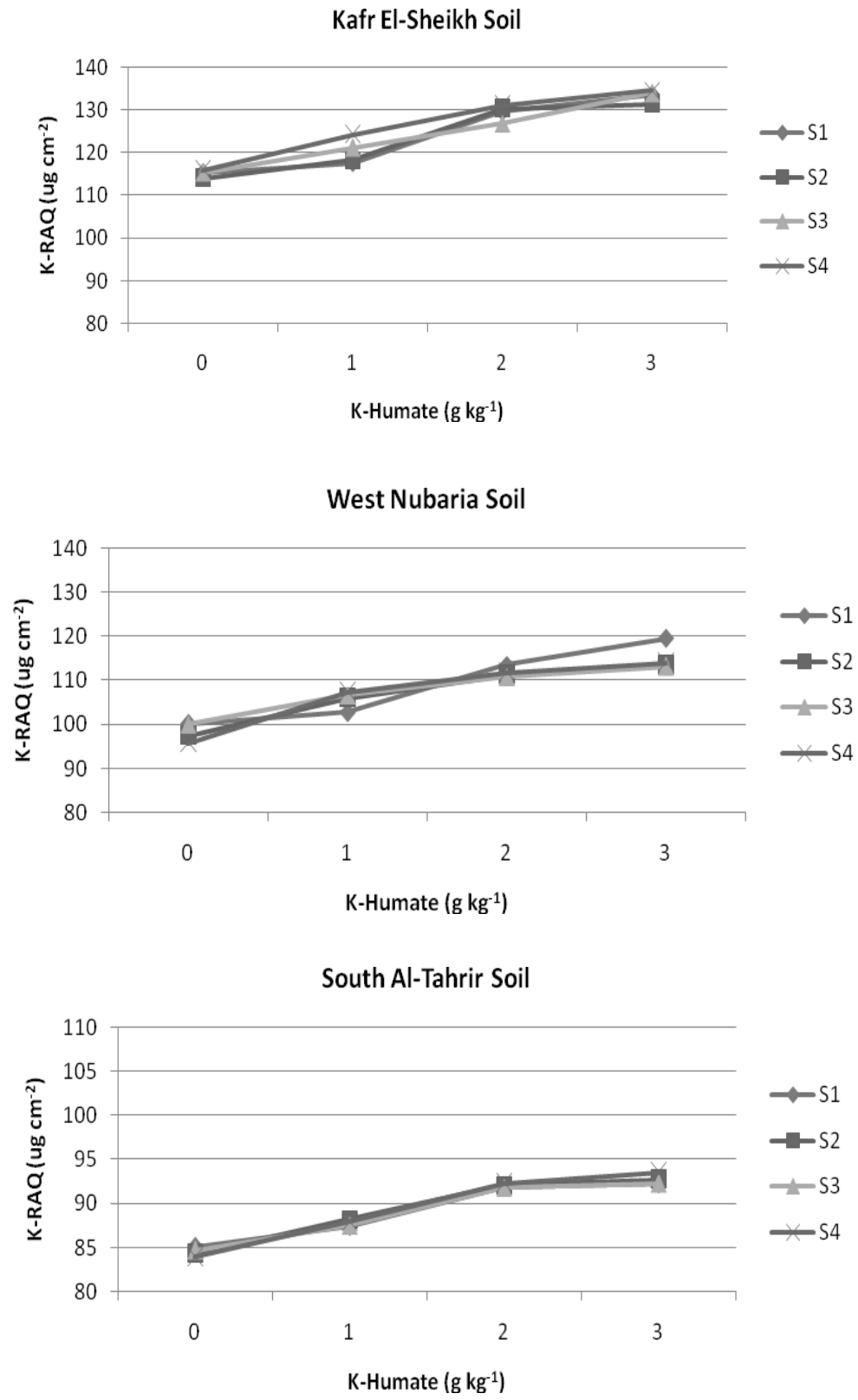

Fig. 3. K-RAQ values as affected by K-Humate application at different salinity levels in the three tested soils. 
TABLE 6. Increase percentage in K-RAQ values relative to the control.

\begin{tabular}{|c|c|c|c|c|}
\hline \multirow{2}{*}{ Soils } & \multirow{2}{*}{$\begin{array}{c}\text { Salinity } \\
\text { Treatments }\end{array}$} & \multicolumn{3}{|c|}{ K-Humate Treatments $\left(\mathrm{g} \mathrm{kg}^{-1}\right)$} \\
\hline & & 1 & 2 & 3 \\
\hline \multirow[t]{4}{*}{ Kafr El-Sheikh } & $\mathrm{S} 1$ & 1.99 & 12.40 & 15.87 \\
\hline & $\mathrm{S} 2$ & 3.78 & 14.31 & 15.36 \\
\hline & S3 & 5.03 & 9.97 & 16.13 \\
\hline & S4 & 7.08 & 13.11 & 16.05 \\
\hline \multirow[t]{4}{*}{ West Nubaria } & $\mathrm{S} 1$ & 2.50 & 13.37 & 19.26 \\
\hline & $\mathrm{S} 2$ & 8.73 & 14.12 & 16.43 \\
\hline & S3 & 6.70 & 10.80 & 13.10 \\
\hline & S4 & 12.12 & 16.72 & 19.12 \\
\hline \multirow[t]{4}{*}{ South Al-Tahrir } & $\mathrm{S} 1$ & 2.70 & 7.99 & 8.34 \\
\hline & $\mathrm{S} 2$ & 4.63 & 9.25 & 9.96 \\
\hline & $\mathrm{S} 3$ & 3.31 & 8.38 & 8.97 \\
\hline & $\mathrm{S} 4$ & 4.77 & 10.01 & 11.44 \\
\hline
\end{tabular}

\section{Conclusion}

Soil application of K-Humate significantly alleviated the adverse effects of soil salinity on N, P and K phytoavailability in the studied soils. Humic substances are thought to improve the soil structure and improve physical properties of soil by increasing the exchange capacity and buffering capacities, promoting the chelation of many elements and making them available to plants. Humic substances may be used in cases where negative effects of salts would inhibit nutrients uptake and plant growth. Under the conditions of our study, the application rates of K-Humate should not exceed $2.0 \mathrm{~g}$ K-Humate/kg soil. Economical feasibility in different plant environments under field conditions requires further research studies.

\section{References}

Aydil, A., Canan, K. and Metin,T. (2012) Humic acid application alleviate salinity stress of bean (Phaseolus vulgaris L.) plants decreasing membrane leakage. African J. Agri. Res. 7, 1073-1086.

Andrews, J. E., Brimblecombe, P., Jickells, T. D., Liss, P. S. and Reid, B. (2004) “An Introduction to Environmental Chemistry", $2^{\text {nd }}$ ed. Blackwell, UK. 
Ashraf, M. and Foolad, M. A. (2007) Improving plant abiotic-stress resistance by exogenous application of osmoprotectants glycine, betaine and proline. Environ. Exp. Bot. 59, 206-216.

Aşık, B.B., Turan, M. A., Çelik, H. and Katkat, V. (2009) Effects of humic substances on plant growth and mineral nutrients uptake of wheat (Triticum durum cv. Salihli) under conditions of salinity. Asian J. Crop Sci., 1, 87-95.

Carlyle, J. C. and Malcolm, D. C. (1986) The use of ion exchange resins bags to assess $\mathrm{N}$ availability beneath pure spruce and larch spruce on a deep peat soil. Plant Soil, 93, $123-127$.

Cooperland, L. R. and Logan, T. J. (1994) Measuring in situ changes in labile soil phosphorous with anion-exchange membranes. Soil Sci. Soc. Am. J. 58, 105-114.

Costat (2004) CoStat: Statistical Analysis Package Ver. 6.303. CoHort Software. CA, USA.

Daur, I. and Bakhashwain, A. A. (2013) Effect of humic acid on growth and quality of maize fodder production. Pak. J. Bot. 45, 21-25.

Dell'Amico, C., Masciandaro, G., Ganni, A., Ceccanti, B., Garcia, C., Hernandez, T. and Costa, F. (1994) Effects of specific humic fractions on plant growth. In Humic Substances in the Global Environment and Implications on Human Health; Senesi, N. and Miano, T.M., Ed.; Elsevier Science: Amsterdam, The Netherlands, pp. 563-566.

Delgado, A., Madrid, A., Kassem, S., Andrew, L. and Campillo, M. (2002) Phosphorus fertilizer recovery from calcareous soils amended with humic and fulvic acids. Plant and Soil, 245, 277-286, 2002.

Grossl, P. R. and Inskeep, W. P. (1991) Precipitation of dicalcium phosphate dihydrate in the presence of organic acids. Soil Sci. Soc. Am. J. 55, 670-675.

Haibara, K., Aiba, Y. and Kawashima, Y. (1990) Use of exchange resin to study the elements in forest soil. Japanese J. Ecol. 40, 19-25.

Havlin, J.L. and Westfall, D.G. (1984) Soil test phosphorus and solubility relationships in calcareous soils. Soil Sci. Soc. Am. J. 48, 327-330.

Hedia, R. M. R. and Sherif, F. K. (2004) Reliability of phytoavailability soil Test using resin capsules in some artificially-salinized Egyptian soils. Alex. J. Agric. Res. 49, 107-117.

Inskeep, W.P. and Silvertooth, J.C. (1988) Inhibition of hydroxyapatite precipitation in the presence of fulvic, humic, and tannic acids. Soil Sci. Soc. Am. J. 52, 941-946.

Keeney, D. R. and Nelson, D. W. (1982) Nitrogen - inorganic forms. In: A.L. Page (Ed.). p. 643-698. "Methods of Soil Analysis", part 2. Agron. Monogr. 9, $2^{\text {nd }}$ ed. ASA and SSSA, Madison, WI

Khaled, H. and Fawy, H. A. (2011) Effect of different levels of humic acids on the nutrient content, plant growth and soil properties under conditions of salinity. Soil \& Water Res. 6, 21-29. 
Kulikova, N.A., Stepanova, E.V. and Koroleva, O.V. (2005) Mitigating activity of humic substances: Direct influence on biota. In: "Use of Humic Substances to Remediate Polluted Environments: From Theory to Practice", NATO Science Series IV: Erath and Environmental Series, Perminova, I.V. (Ed). pp. 285-309. Kluwer Academic Publishers, USA.

Marschner, H. (1995) Mineral Nutrition of Higher Plants $\left(2^{\text {nd }}\right.$. ed) (p. 446). London, GB: Academic Press. Inc.

Masciandaro, G., Ceccanti, B., Ronchi, V., Benedicto, S. and Howard, L. (2002) Humic substances to reduce salt effect on plant germination and growth. Commun. Soil. Sci. Plant. Anal. 33, 365-378.

Mesut Çimrin, K., Türkmen, Ö., Turan, M. and Tuncer, B. (2010) Phosphorus and humic acid application alleviate salinity stress of pepper seedling. African J.Biot. 36, 5845-5851.

Page, A. L., Miller, R. H. and Keeney, D. R. (1982) "Methods of Soil Analysis". Part II. $2^{n d}$ ed. Agron. Monogr. 9 Madison, Wisconson, U.S.A.

Sherif, F. K. (1996) Phytoavailability of zinc and copper by soybean and wheat growing in sand culture and sewage sludge amended soil in relation to plant growth and metal mobility in soil. Ph.D. Thesis. Faculty of Agriculture, University of Alexandria. Alexandria. Egypt.

Sherif, F. K. and Hedia, R. M. R. (2001) Evaluation of resin capsules for monitoring availability and movement of nutrients in Egyptian soils. Alex. J. Agric. Res. 46,119-128.

Skogley, E.O. (1992) The universal Bioavailability Environment/Soil Test: UNIBEST. Coummun. Soil Sci. Anal. 23, 2225-2246.

Skogley, E. O. (1994) Reinventing soil testing for future. In: "Soil Testing: Prospects for Improving Nutrient Recommendation”. p. 187-201. In J.L. Havlin et al. (Ed.) SSSA Spec. Publ. 40 ASA and SSSA, Madison, WI.

Steel, R. G. D. and Torrie, J. H. (1980) "Principles and Procedures of Statistics. A Biometrical Approach”. McGraw-Hill, New York.

Tester, M. and Davenport, R. (2003) $\mathrm{Na}^{+}$tolerance and $\mathrm{Na}^{+}$transport in higher plants. Annals of Botany, 91, 503-527.

van Raij, B., Quaggio, J. H. and DeSilva, N M. (1986) Extraction of phosphorus, potassium, calcium, and magnesium from soils by an ion exchange resins procedure. Comm. Soil Sci. Plant Anal. 17, 547-566.

Walker, D. J. and Bernal, M. P. (2008) The effects of olive mill waste compost and poultry manure on the availability and plant uptake of nutrients in a highly saline soil. Bioresour. Technol. 99, 396-403.

Wander, M.M., Shuman, L.M., Johnson, J.W. and Box, J. E. (1995) Anion exchange membranes used to assess management impacts on soil nitrate. Comm. Soil Sci. Plant Anal. 26, 2383-2390.

Egypt. J. Soil Sci. 55, No.3 (2015) 
Wimaladasa, G.D. and Sinclair, A.H. (1988) Ion exchange resin and soil solution measurements of soil potassium and its uptake by ryegrass and clover. Anal. Proc. 25, 65-67.

Yang, J. E., Skogley, E.O., Schaff, B.E. and Ferguson, A.H. (1991) Phytoavailability soil test: Development and verification of theory. Soil Sci. Soc. Am. J. 55,13581365.

(Received 24/2/2014; accepted 30/12/2015)

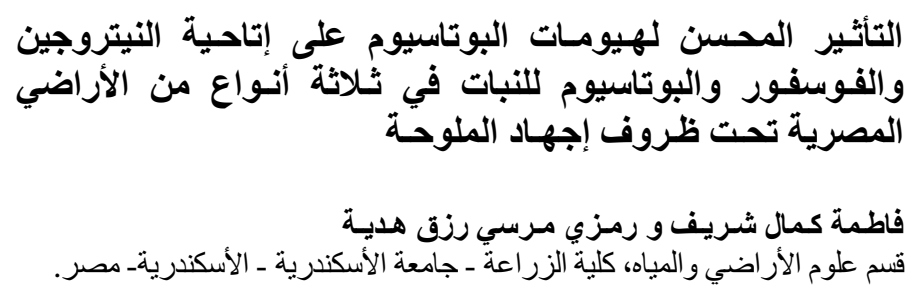

تؤدي زيادة ملوحة التربة إلى العديد من التآثيرات السلبية على إتاحية العناصر

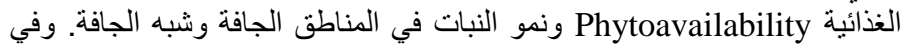

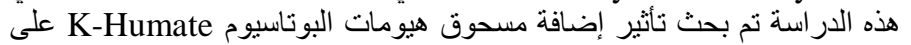

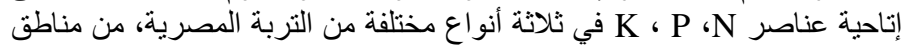

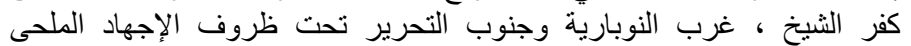

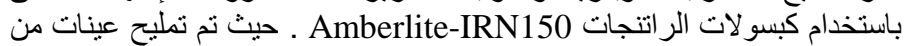

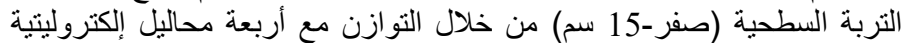

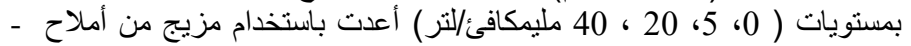

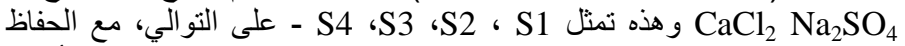

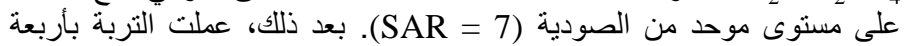
معدلات من مسحوف هيومات البوتاسيوم (0, 1, 2, 3 g/kg soil) تحت كل كل

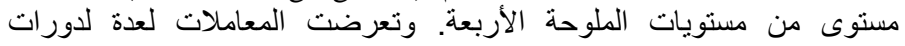

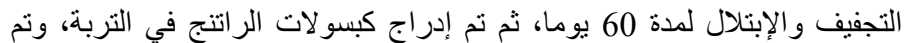

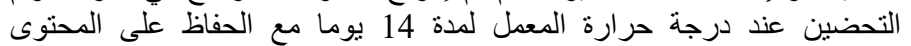

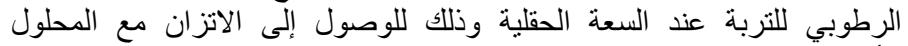

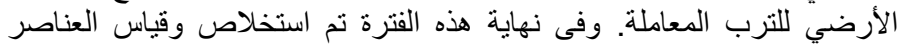

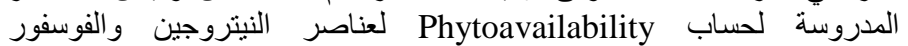
و البوتاسيوم (RAQ,

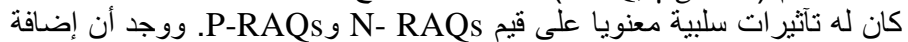

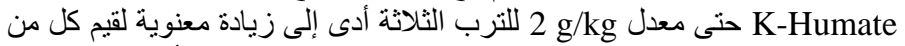
N-RAQs

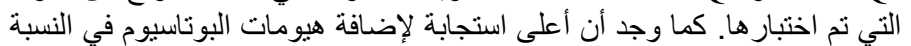

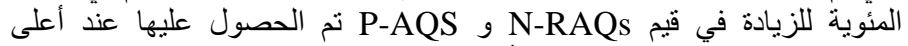
مستوى من ملوحة التربة S4 في الأنو اع الثلاثثة من التربة. في حين لم تؤثثر زيادة

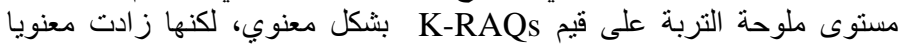

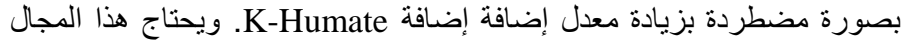

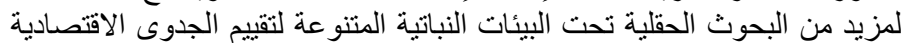

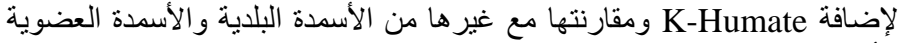

$$
\text { الأخرى. }
$$

